International Journal of Current Advanced Research

ISSN: O: 2319-6475, ISSN: P: 2319 - 6505, Impact Factor: SJIF: 5.995

Available Online at www.journalijcar.org

Volume 6; Issue 4; April 2017; Page No. 3444-3446

DOI: http://dx.doi.org/10.24327/ijcar.2017.3446.0289

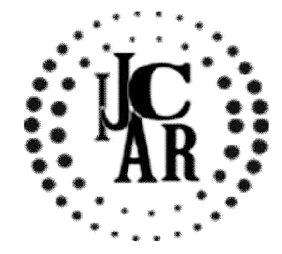

Research Article

\title{
IN VITRO EVALUATION OF ANTI MYCOTIC ACTIVITY OF ZINGIBER OFFICINALEEXTRACT ON CANDIDA ALBICANS
}

\author{
Ashik Ahamed A* and Geetha R V
}

Saveetha Dental College and Hospitals Saveetha University Chennai-600077

\begin{tabular}{l}
\hline A R T I C L E I N F O \\
Article History: \\
Received $16^{\text {th }}$ January, 2017 \\
Received in revised form $20^{\text {th }}$ February, 2017 \\
Accepted $22^{\text {nd }}$ March, 2017 \\
Published online $28^{\text {th }}$ April, 2017
\end{tabular}

\section{Key words:}

Antimycotic, Zingiberofficinale, Agar well diffusion, Zone of Inhibition.

\begin{abstract}
A B S T R A C T
Introduction: An anti mycotic is a substance that kills or inhibits the growth of fungi. Zingiberofficinale has been valued as a zesty spice and a reliable medicinal herb for centuries.It has various herbal actions. The medicinal uses of ginger have been known for at least 2,000 years in cultures all around the world. It is a flavouring agent in beer, soft drinks, candies, and a staple spice. Effect of Zingiberofficinale extract on Candida albicans is determined.

Aim: To evaluate the antimycotic activity of Zingiberofficinale extract on Candida albicans.

Methodology: The antimycotic activity is carried out by agar well diffusion technique against the fungal pathogens and the zone of inhibition is measured in $\mathrm{mm}$ diameter.

Result: In the present study, Zingiberofficinale was found to be effective against grampositive Candida albicans organisms tested.
\end{abstract}

Copyright $\bigcirc 2017$ Ashik Ahamed A and Geetha $\mathbf{R}$ V. This is an open access article distributed under the Creative Commons Attribution License, which permits unrestricted use, distribution, and reproduction in any medium, provided the original work is properly cited.

\section{INTRODUCTION}

Infectious diseases are the major cause for health problems in developing countries like India ${ }^{[1]}$. Medicinal plants represents a rich source of antimicrobial agents. Plants are used medicinally in different countries and are the resource of many potent and powerful drugs ${ }^{[2] .}$ Plant herbs are naturally gifted at the synthesis of medicinal compounds. The use of herbs to treat disease is almost universal and is often more affordable than expensive modern pharmaceuticals. Many of the phytochemicals found in the herbs have beneficial effects and can be used to treat human diseases ${ }^{[3]}$. The extraction and characterisation of bioactive compounds from medicinal plants have resulted in the discovery of new drugs with high therapeutic value ${ }^{[4]}$. Zingiberofficinale (commonly called as ginger) has many uses. Ginger belongs to Zingiberaceae family. The Zingiberaceous plants are characterised by their tuberous or non tuberous rhizomes which have strong aromatic and medicinal properties. Traditional uses of plants have led to investigating their bioactive compoundswhich have resulted in the detection of a significant number of therapeutic properties ${ }^{[5,6]}$. In traditional Indian medicine or Ayurveda Zingiberofficinale and many other herbs have been used as medicine ${ }^{[7]}$. Medicinal plants has been used in different application especially to treat different pathogenesis of microorganisms in the world. The pathogenic include yeast such as Candida is resistance to several drugs like

*Corresponding author: Ashik Ahamed A

Saveetha Dental College and Hospitals Saveetha University Chennai-600077 cycloheximide, fluconazole, nystatin and griseofulvin this resistance was increased in recent years because of several mechanisms developed like genetic changes in some genes through mutations that cause changes in some enzyme pathway ${ }^{[8]}$. In the past few decades a worldwide increase in the incidence of fungal infections has been observed. The majority of anti fungal drugs used clinically have many drawbacks like toxicity, efficacy and cosy and their frequent use led to resistance strain ${ }^{[9]}$. Candida is a normal commensal of the oral cavity. However in immunocompromised individuals candidiasis is the earliest infection to manifest ${ }^{[10]}$. Recently many plant extracts have shown to have therapeutic values with respect to oral diseases ${ }^{[11,12,13]}$. The present study was carried out to assess the effect of Zingiberofficinale extract against Candida albicans in vitro.

\section{MATERIAL AND METHODS}

\section{Materials}

The Bacterial strains used was Candida albicans. The organisms was obtained from Department of Microbiology, Saveetha Dental College and Hospitals.

\section{Methodology}

The Zingiberofficinalepowder was dissolved in distilled water in following concentrations $2.5 \mathrm{mg} / \mathrm{ml}, 5 \mathrm{mg} / \mathrm{ml}$ and $10 \mathrm{mg} / \mathrm{ml}$ so that $100 \mu \mathrm{l}$ delivers $250 \mu \mathrm{g} / \mathrm{ml}, 500 \mu \mathrm{g} / \mathrm{ml}$ and $1000 \mu \mathrm{g} / \mathrm{ml}$ respectively. 


\section{Agar well diffusion technique}

Broth culture of the test organisms compared to Mac Farland's standard 0.5 were prepared. Lawn culture of the test organisms were made on the Muller-Hinton agar [MHAM1084] plates using sterile cotton swab and the plates were dried for 15 minutes. Well measuring $4 \mathrm{~mm}$ depth was made on the agar with sterile cork borer. $100 \mu l$ of the extract was added to the wells. The plates were incubated overnight and the zone of inhibition of growth was measured in $\mathrm{mm}$ diameter. All the test were done in triplicate to minimise the test error.

\section{RESULT}

The antimycotic activity of the ginger extract at different concentrations was screened by agar well diffusion technique and the zone of inhibition was measured in $\mathrm{mm}$ diameter. The results are given in the table 1.The activity of Zingiberofficinaleextract was compared with the control. Different concentrations $(250 \mu \mathrm{g} / \mathrm{ml}, 500 \mu \mathrm{g} / \mathrm{ml}, 1000 \mu \mathrm{g} / \mathrm{ml})$ of extract were used and the zone of inhibition was measured. When the concentration is $250 \mu \mathrm{g} / \mathrm{ml}$ the inhibition was found to be $20 \mathrm{~mm}$ diameter. Similarly for $500 \mu \mathrm{g} / \mathrm{ml}$ and $1000 \mu \mathrm{g} / \mathrm{ml}$ it was found to be 26 and $29 \mathrm{~mm}$ diameter and for the control it is $22 \mathrm{~mm}$ diameter. The result shows that as the concentration of the extract increases the zone of inhibition also increases.

\section{DISCUSSION}

There are various uses of Ginger which includes anti emetic activity, anti ulcer, anti-platelet, antipyretic, anti inflammatory and antioxidant activity. Ginger has various phytochemicals like gingerols, zingibain, bisabolene, oleoresins, starch. The use of phytochemicals derived from plants, with known antimicrobial properties, are of great significance to medicinal treatments. Ginger extract containing Gingerol inhibits the growth of many bacteria and fungi in-vitro and the activity might be contributed to the preventive effects of its different agents.

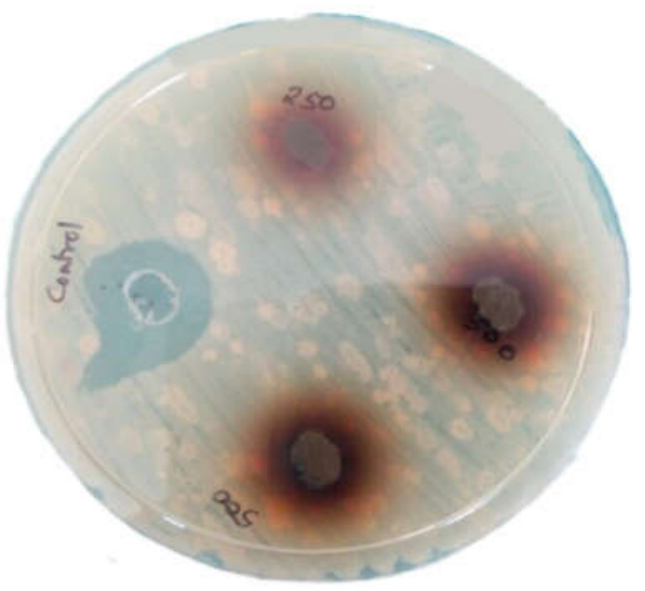

Figure 1

(Figure showing antimycotic activity of candida albicans by using agar well diffusion method)
Table 1 Antimycoticactivity of Zingiberofficinale

\begin{tabular}{|l|l|}
\hline $\begin{array}{l}\text { Conc of Extract } \\
\mu g / m l\end{array}$ & $\begin{array}{l}\text { Zone of Inhibition } \\
\text { mm diameter }\end{array}$ \\
\hline 250 & 20 \\
\hline 500 & 26 \\
\hline 1000 & 29 \\
\hline Control & 22 \\
\hline
\end{tabular}

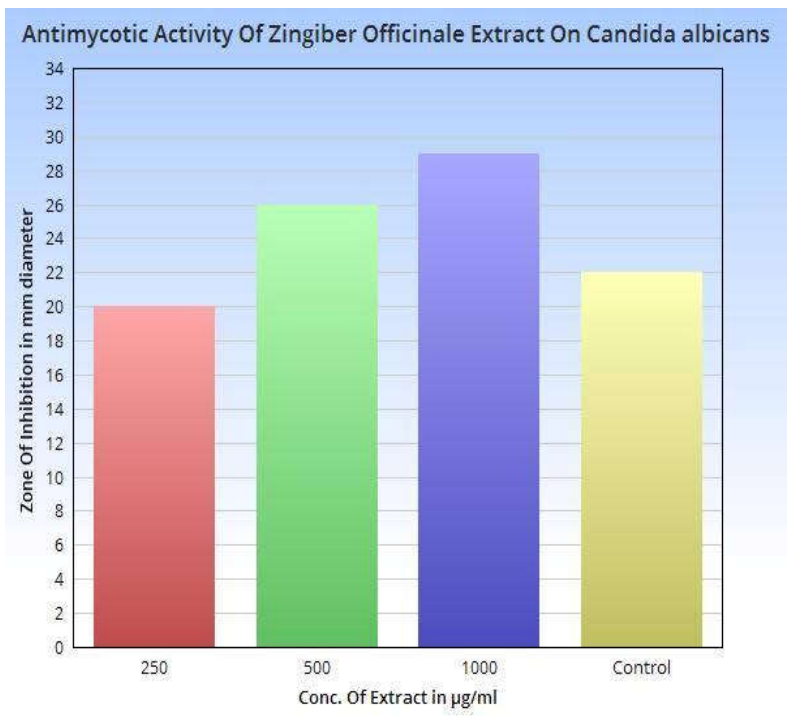

\section{CONCLUSION}

The results of this study suggest good correlation between medicinal use and the in vitro antimycotic activity. It has been concluded from present study that certain plant extracts are a source of cheap and effective fungicides of ginger extract and also it doesn't have human and environment health implications. The results of our present study shows the extract used have significant antibacterial action on the bacterial agents tested.

\section{References}

1. M.Ashfaq Ahamed, Gayathri R, Vishnu priya V. Anti fungal activity of Neem oil. Int.J.Pharm.Sci.Rev.Res., 39(1), July-August 2016; Article No.38, Pages: 200202.

2. Anitha Roy, Geetha R.V, Lakshmi T. In vitro evalution of Anti mycotic activity of Heartwood Extract of Acacia catechu willd. Journal of Pharmacy Research 2011, 4(7), 2010-2011.

3. R.V.Geetha, Roy Anitha. In vitro evalution of anti mycotic activity of Ethanolic extract of GlycyrrhizaGlabra. Asian Journal of Pharmaceutical and Clinical Research Vol 6, Issue 3, 2013.

4. Mirghani, M.E.S., Liyana, Y. and Parveen, J. Bioactivity analysis of lemongrass (Cymbopogancitratus) essential oil. International Food Research Journal 19(2): 569-575 (2012).

5. Sharma S, Vijayvergia R, Singh T. Evaluation of antimicrobial efficacy of some medicinal plants. $J$. Chem. Pharm. Res., 2010,2(1):121-124.

6. Chen I-N, Chang C-C, Ng C-C, Wang C-Y, Y-T Shyu, Chang T-L. Antioxident and antimicrobial acivity of Zingiberaceous plants in Taiwan. Plants Foods Hum Nutr (2008)63: 15-20. 
7. http://icmr.nic.in/BUJUNEO3nwe.pdf ICMR Bulletin. Ginger: Its Role in Xenobiotic Metabolism. Accessed on $29 / 08 / 2010$.

8. Mona Al-Terehi, Ali H. Al-Saadi, HaiderK.Zaidan, Zahraa H. Alkaim, Rajaa Ali Habeeb, NooraMajed. Some herbal medicinal plants activity against Candida spp which resistance to antifungal drugs. International Journal of PharmTech Research Vol.8, No.10,pp 146150, 2015.

9. Supreetha.S., SharadadeviMannur, Sequeira Peter Simon, Jitheshjain, ShreyasTikare, Amit Mahuli. Antifungal Activity of Ginger Extract on Candida Albicans: An invitro Study. Journal of Dental Sciences and Research Vol. 2, Issue 2, Pages 1-5.
10. Atai Z, Atapour M, Mohseni M. Inhibitory effect of Ginger Extract on Candida Albicans. Am.J.Applied Sci.m6(6):1067-1069,2009.

11. Bakri I M, Douglas CWI. Inhibitory effect of garlic extract on oral bactyeria. Arch. Oral Biol., 50:645-651.

12. Prashant GM, Chandu GN, Murulikrishna KS, Shafiulla MD. The effect of mango and neem extract on four organisms causing dental caries: Streptococcus mutans, Streptococcus salvarius, Streptococcus mitis, and Streptococcus sanguis: An in vitro study. Indian $J$ Dent Res, 18(4), 2007.

13. Ficker CE et al. Inhibition of human pathogenic fungi by members of Zingiberaceae used by the Kenyah (Indonesian Borneo). J. Ethnopharmacol., 85: 289-293.

\section{How to cite this article:}

Ashik Ahamed A and Geetha R V (2017) ' In Vitro Evaluation Of Anti Mycotic Activity Of Zingiber Officinale extract On Candida Albicans', International Journal of Current Advanced Research, 06(04), pp. 3444-3446.

DOI: http://dx.doi.org/10.24327/ijcar.2017.3446.0289 